\title{
Subglottic Cancer pT4a TNM Finding v6
}

National Cancer Institute

\section{Source}

National Cancer Institute. Subglottic Cancer pT 4a TNM Finding v6. NCI Thesaurus. Code C64720.

Subglottic cancer with tumor invading cricoid or thyroid cartilage and/or invading tissues behind the larynx (e.g. trachea, soft tissues of neck including deep extrinsic muscles of the tongue, strap muscles, thyroid, or esophagus). (from AJCC 6th Ed.) 